\title{
Agreement among methods for study estimation of elderly height at the nutrition ambulatory
}

Bruna Calixto Sant'Anna'

Gisella Meireles de Castro Lage2 Silvia Maria Custódio das Dores' Luis Guillermo Coca Velarde ${ }^{3}$

Sérgio Girão Barroso ${ }^{1}$ Gabrielle de Souza Rocha'

\section{Abstract}

Objective: to evaluate methods of elderly height estimation attended at the Nutrition ambulatory. Method: a total of 43 elderly individuals of both genders were evaluated during nutrition consultations. Sociodemographic data were collected from charts and height, knee height, arms wingspan and semi-span were measured. Statistical analysis were made through Bland-Altman test to evaluate concordance among statures estimated by predictive formulas and the height measured. Results: the values found were: height measured in meters $1.53( \pm 0.08)$, height estimated by the wingspan $1.60( \pm 0.10)$, by the semi-span $1.61( \pm 0.11)$ and by the knee height $1.56( \pm 0.10)$. According to the Bland-Altman graph, the height estimated by knee height showed a better agreement with the measured height. Conclusion: according to this study results, poor predictive formulas concordance in height estimation in elderly, using the measures: arms wingspan and semi-span with real stature measured were observed. Knee height, using Chumlea formula, presented the best concordance with measured stature and seems to be a good way for stature estimation at the studied population.

\footnotetext{
Universidade Federal Fluminense, Faculdade de Nutrição Emília de Jesus Ferreiro, Departamento de Nutrição e Dietética, Programa de Pós-graduação em Saúde do Idosos. Niterói, Rio de Janeiro, Brasil.

2 Universidade Federal Fluminense, Faculdade de Nutrição Emília de Jesus Ferreiro, Departamento de Nutrição e Dietética, Programa de Graduação em Nutrição. Niterói, Rio de Janeiro, Brasil.

3 Universidade Federal Fluminense, Instituto de Matemática e Estatística, Departamento de Estatística. Niterói, Rio de Janeiro, Brasil.
}

Keywords: Health of the Elderly. Nutrition Assessment. Body Height. 


\section{INTRODUCTION}

The physiological changes caused by time have an impact on elders nutritional and health status ${ }^{1}$. There is a decrease in body water, causing changes in skin elasticity and a change in body composition due to a decrease in the basal metabolic rate, resulting in an increase in body fat mainly in the abdominal region, among other alterations ${ }^{2}$. In addition, depletion of skeletal muscle tissue associated with decreased strength and functionality characterizes sarcopenia in the elderly ${ }^{3}$.

Changes in elders nutritional status are also associated with sensory modifications, such as altered taste and reduced sensitivity, one of the most relevant factors in food consumption reduction in the elderly. The use of medications may also interfere with certain foods ingestion, digestion and absorption ${ }^{4}$.

Thus, it is important to use nutritional assessment tools considering elders physiological changes. Nutritional status evaluation encompasses several methods and techniques, as anthropometric measures, specially body weight and height. Both measures are indispensable for establishing nutritional diagnosis and calculating nutritional needs ${ }^{5,6}$.

In the elderly population, it is common to find individuals who are unable to stand, making it difficult to measure their height and weight. Another important factor is the evidence of decreasing individuals stature after 40 years of age, decreasing from one to two and a half centimeters per decade. This reduction in height is due to changes in spine during aging process ${ }^{7}$.

In these cases, there are several methods to estimate weight and height, among them, predictive formulas, using measures such as: knee height $(\mathrm{KH})$, wingspan and semi-span to estimate stature ${ }^{8}$. Weight can be estimated, through estimated height and Body Mass Index (BMI), using the reference range of the World Health Organization (WHO), among other methods?

These formulas are routinely used in clinical practice for anthropometric evaluation and nutritional needs calculation, however, the accuracy and precision of these are little known for Brazilian elderly ${ }^{10}$. Therefore, the study aims to evaluate the agreement between the methods of height estimates and the measured height of elderly patients attended in a outpatient clinic.

\section{METHOD}

A cross-sectional observational study was carried out, comprising 43 elderly patients, aged $\geq 60$ years, attended at the Nutrition Outpatient Clinic located at the Reference Center for Health Care of Elderly (CRASI / Mequinho), Universidade Federal Fluminense (UFF).

To determine the sample size, the procedure based on the operating characteristic curves was used. This procedure limits the error to be made when not rejecting $\mathrm{HO}$ ('Type II error), based on the relation between the deviation of the analyzed variable according to its standard deviation. A 20\% probability was defined for the occurrence of Type II error ( $\beta$ risk). It was also defined the deviation "D" between variables analyzed in the study and its variability would be at most $45 \%$, where:

$$
\mathrm{D}=\frac{(\mathrm{X}-\mu 0)}{\delta}
$$

With these values, the characteristic curve for bilateral tests with $\alpha=5 \%$, the value of $\mathrm{N}=40$ was withdrawn, with $\mathrm{N}$ being the minimum number of patients needed to enter the survey ${ }^{11}$.

CRASI serves elderly people living in the cities of Niterói, Itaboraí, Maricá, Rio Bonito, São Gonçalo, Silva Jardim and Tanguá. It offers outpatient geriatric, nutrition and psychology services, as well as groups of coexistence with cognitive stimulation and physical exercise practice.

Patients are referred to the nutrition outpatient clinic by the geriatrician or by a professional in the cohabitation group. During consultation, sociodemographic data are collected and a nutritional assessment is done through clinical anamnesis and anthropometric measurements, as a part of the ambulatory care protocol. These measures are done by two nutritionists trained to perform anthropometry.

Individuals arriving at the outpatient clinic for nutritional consultation underwent evaluations according to the outpatient protocol. At the end 
of the consultation, they were informed about the study proposal and invited to attend. Individuals who accepted, signed the Term of Free and Informed Consent (TCLE).

The following inclusion criteria were used: elderly patients, age $\geq 60$ years, of both genders, with decision autonomy and who were able to perform all anthropometric measurements. As exclusion criterion: patients who presented with some clinical condition interfering in anthropometric measures determination, such as patients not able to stand, with amputations, edema or ascite.

The following anthropometric measures were evaluated: height, $\mathrm{KH}$, wingspan and semi-span. Height was measured as described by Guedes and Guedes $^{12}$.

To measure KH, flexible and non-elastic metric tape was used with the patient sitting, bending the knee to form a $90^{\circ}$ angle. The tape was positioned from the base of the heel to the head of the fibula. To estimate height, the Chumlea formula ${ }^{13,14}$ was used, and the protocol described by Rosa et al. ${ }^{8}$ was used to measure the wingspan and semi-span.

The graph proposed by Bland-Altman was used, with the measures estimated and measured, to analyze agreement between them ${ }^{15}$. The limits of agreement are estimated by the mean difference $( \pm 1.96)$, assuming that the differences are normally distributed $^{16}$. Also, the Pearson correlation coefficient was determined between variables. Statistical analyzes were performed through statistical program.
The data that were collected in this study are already part of the consultation protocol of the Nutrition Outpatient Clinic (CRASI-UFF). The project was submitted to the ethics committee of the Universidade Federal Fluminense and approved under the number of opinion 1.836.802.

\section{RESULTS}

The study included 43 patients, $88.37 \%$ female, mean age was 74 years ( \pm 7.1 ), $55.8 \%$ of the participants lived in the city of Niterói and 31.53\% in other municipalities (Table 1).

Mean height measured in meters was $1.53( \pm$ 0.08), for height estimated by the wingspan 1.60 $( \pm 0.10)$, for the semi-span $1.61( \pm 0.11)$ and for the knee height $1.56( \pm 0.10)$.

According to Pearson's correlation, the stature measured and those estimated by the wingspan $(\mathrm{r}$ $=0.89, p<0.0001)$, semi-span $(\mathrm{r}=0.86, p<0.0001)$ and knee height $(\mathrm{r}=0.69, p<0.0001)$ presented a strong positive correlation (Figure 1).

In Figure 2, the Bland-Altman graphs are presented. This graph shows good agreement only when the points on the graph lie close to the horizontal solid line, with 95\% concordance limits represented by horizontal dotted lines. It was observed the stature measured and the estimated with wingspan, as well as with the semi-span did not present good agreement. The measured height and the knee height showed good agreement.

Table 1. Sociodemographic characteristics of patients attended at the Nutrition outpatient clinic of the Center for Reference and Health Care of the Elderly $(\mathrm{N}=43)$. Niterói, RJ, 2016.

\begin{tabular}{ll}
\hline Variables & $\mathrm{n}(\%)$ \\
\hline Sex & $38(88.37)$ \\
Female & $5(11.63)$ \\
Male & \\
\hline Age (years) & $43(100)$ \\
$74.51( \pm 7.09)$ & \\
Country & $24(55.81)$ \\
Niterói & $17(39.53)$ \\
São Gonçalo & $1(2.32)$ \\
Itaboraí & $1(2.32)$ \\
Rio Bonito & \\
\hline
\end{tabular}




\section{Pearson's Correlation}
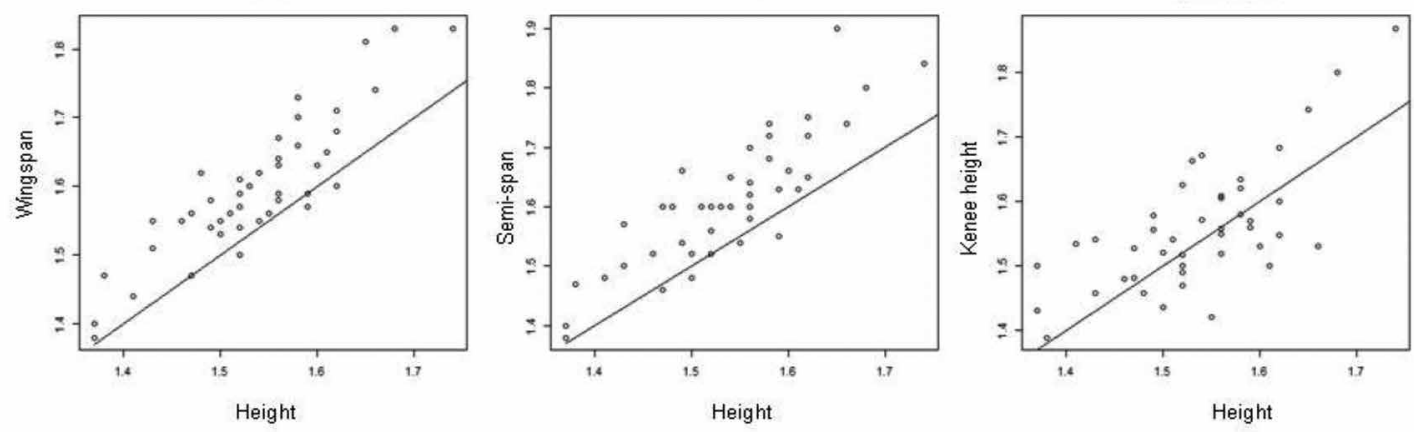

Figure 1. Measured stature and span, measured and semi-span stature, measured stature and knee height. Niterói, RJ, 2016.

\section{Bland Altman Graphics}
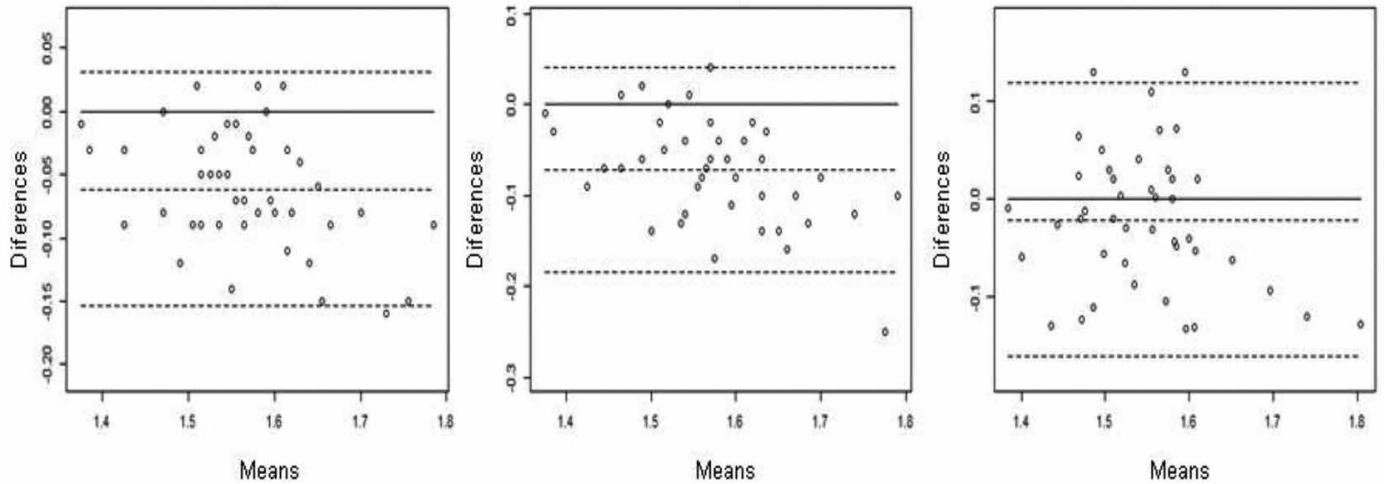

Figure 2. Analysis of concordance between measured stature and span, stature measured and semi-span, stature measured and knee height. Niterói, RJ, 2016.

\section{DISCUSSION}

The present study evaluated elderly attending CRASI/UFF nutrition clinic. The higher proportion of women has already been described in other studies and can be explained by differences in mortality between the sexes, where men tend to die earlier, since women have less exposure to risk factors, such as smoking and alcoholism, and seek more the health services, with a higher life expectancy ${ }^{17,18}$.

Regarding the methods of height estimating in elderly, after the statistical tests were applied, the results did not show good agreement in the measured stature and the estimated with arm span, where a variation of approximately $10 \mathrm{~cm}$ was found, being relevant in clinical practice, because if the predictive formula overestimates height, it would impact on estimated weight and, following errors on nutritional needs calculations ${ }^{19}$. Analyzing the measured height and the estimated semi-span of the arms, it was also observed an overestimation on height, but with a smaller variation when compared to the wingspan, approximately two centimeters.

One study found data corroborating the present study. The authors evaluated predictive formulas applicability for weight and height in 98 adult men. 
The results also showed the measures of wingspan and semi-span overestimating individuals stature ${ }^{20}$.

Melo et al. ${ }^{6}$, when evaluating estimated height in a sample of 142 adults of both sexes, using the Means Comparison Test, observed a significant difference between measured stature and estimated height by semi-span. However, these tests do not seem to be the most adequate in this type of evaluation ${ }^{14}$.

In a study of 30 adult and elderly patients hospitalized at the Intensive Care Unit at a University Hospital in Rio de Janeiro, authors evaluated the concordance between recumbent stature and the estimated through Chumlea formula, the semispan and the patient or family report. Semi-span presented lower concordance when compared to other measures, suggesting in clinical practice, semispan would not be a good option ${ }^{20}$.

When assessing measured height and knee height using Chumlea formula, good agreement was observed, with the lowest height variation, approximately one centimeter.

In the study by Souza et al. ${ }^{10}$, measured height and the Chumlea formula were also evaluated, in a sample of 131 elderly people. The results showed a variation between measurements of approximately two centimeters, probably not clinically relevant when one considers the subsequent calculations (weight estimation and nutritional needs).

\section{REFERENCES}

1. Brandão JM, Fernandes CS, Barroso SG, Rocha GS. Associação do consumo de fibras e risco cardiovascular em pacientes idosos. Int J Cardiovasc Sci. 2015;28(6):464-71.

2. Silva JL, Marques APO, Leal MCC, Alencar DL, Melo EMA. Fatores associados à desnutrição em idosos institucionalizados. Rev Bras Geriatr Gerontol. 2015;18(2):443-51.

3. Cruz-Jentoft AJ, Baeyens JP, Bauer JM, Boirie Y. Sarcopenia: European consensus on definition and diagnosis: report of the European Working Group on Sarcopenia in Older People. Age Ageing. 2010;39(4):412-23.
Melo et al. ${ }^{6}$ evaluated methods to estimate height, among them, Chumlea formula, with a sample composed of 142 adults of both sexes. This formula was the only one not presenting significant difference with the measured stature. The authors suggest this formula as a measure of easy application in clinical practice.

Santos $^{21}$ also, when comparing methods of height estimation, observed Chumlea formula as the best option in relation to the estimated by semi-span, as observed in the present study, where knee height using the Chumlea formula was the best alternative for estimating stature in elderly individuals.

In this study, it was not possible to evaluate all the elderly patients attending the nutrition clinic, and for this reason, the sample size consisted of only 43 elderly individuals, the majority female, not allowing the adequacy assessment of the use of predictive formulas for elderly men and elderly women.

\section{CONCLUSION}

According to the results presented in this study, it was not observed good agreement of the predictive formulas for estimation of height in the elderly, using wingspan and semi-span, with the measured stature. Knee height, using Chumlea formula, presented the best concordance with the measured stature and seems to be a good way for stature estimation of the studied population.

4. Souza LC, Queiroz PT, Burgos MGPA Aplicabilidade da MAN- Mini avaliação nutricional em idosos. Nutr clin diet hosp. 2017;37(1):67-74.

5. Silva ALSC, Silva BS, Brandão JM, Barroso SG, Rocha GS. Avaliação antropométrica de idosos atendidos no Ambulatório de Nutrição do Centro de Referência em Assistência à Saúde do Idoso da Universidade Federal Fluminense, no município de Niterói-RJ. Demetra. 2015;10(2):361-74.

6. Melo APF, Sales RKS, Vieira FGK, Ferreira MG. Métodos de estimativa de peso corporal e altura em adultos hospitalizados: uma análise comparativa. Rev Bras Cineantropom Desempenho Hum. 2014;16(4):475-84. 
7. Freitas AMP, Philippi ST, Ribeiro SML. Listas de alimentos relacionadas ao consumo alimentar de um grupo de idosos: análises e perspectivas. Rev Bras Epidemiol. 2011;14(1):161-77.

8. Rosa G, Pereira AF, Bento CT, Rosado EL, Lopes MSM, Peres WAF. Avaliação nutricional do paciente hospitalizado: uma abordagem teórico-prática. Rio de Janeiro: Guanabara Koogan; 2012.

9. Organização das Nações Unidas no Brasil [Internet]. Rio de Janeiro: UNIC Rio; 2014. Envelhecer bem deve ser prioridade mundial. $\mathrm{O}$ mundo terá 2 bilhões de idosos em 2050 [...]; 2014 [acesso em 26 out. 2016];1 tela. Disponível em: https://nacoesunidas. org/mundo-tera-2-bilhoes-de-idosos-em-2050-omsdiz-que-envelhecer-bem-deve-ser-prioridade-global/

10. Souza R, Fraga JS, Gotschall CBA, Busnello FM, Rabito EI. Avaliação antropométrica em idosos: estimativas de peso e altura e concordância entre classificações de IMC. Rev Bras Geriatr Gerontol. 2013;16(1):81-90.

11. Montgomery DC, Runger GC. Applied statistics and probability for engineers New Jersey: John Wiley \& Sons; 2014.

12. Guedes DP, Guedes JERP. Manual prático para avaliação em Educação Física. São Paulo: Manole; 2006.

13. Chumlea WC, Roche AF, Steinbaugh ML. Estimating stature from knee height for persons 60 to 90 years age. J Am Geriatr Soc. 1985;33(2):116-20.
14. Chumlea WMC, GUO SS. Equations for predicting stature in white and black elderly individuals. J Gerentol. 1992;47(6):197-203.

15. Miot HA. Analise de concordância em estudos clínicos e experimentais. J Vasc Bras. 2016;15(2):89-92.

16. Lucca A. Validade e confiabilidade do peso, estatura e IMC auto-referidos obtidos em entrevistas telefônicas [tese]. São Paulo: Universidade de São Paulo; 2006.

17. Closs E, Feoli AMP, Schwanke CHA. Altura do joelho como medida alternativa confiável na avaliação nutricional de idosos. Rev Nutr. 2015;28(5):475-84.

18. Amorim TC, Burgos MGPA, Cabral PC. Perfil Clínico e antropométrico de pacientes idosos com diabetes mellitus tipo 2 atendidos em ambulatório. Sci Med. 2017;27(3):1-5.

19. Merhi VA, Morete JL, Oliveira MRM. Avaliação do estado nutricional precedente ao uso de nutrição enteral. Arq Gastroenterol. 2009;46(3):219-24.

20. Rezende AC, Rosado LEF, Franceschinn SCC, Rosado GP, Ribeiro RCL. Avaliação da aplicabilidade de fórmulas preditivas de peso e estatura em homens adultos. Rev Nutr. 2009;22(4):443-51.

21. Santos JGC. Comparação entre métodos de estimativa de peso, estatura e necessidades nutricionais em pacientes críticos hospitalizados no centro de terapia intensiva de um hospital universitário no Rio de Janeiro. Rio de Janeiro: Universidade Estadual do Rio de Janeiro; 2016. 